\title{
Indonesia-German Cooperation in Vocational Education and Training
}

\author{
Astrid Wiriadidjaja, Lelly Andriasanti, Andrea Jane \\ Email : astrid.wiriadidjaja@iuli.ac.id , lelly.andriasanti@iuli.ac.id, karmajanaandrea@gmail.com \\ International University Liaison Indonesia, BSD, Indonesia
}

Article Info :

\section{Article history :}

Received : August 2, 2019

Revised : August 29, 2019

Accepted : October 11, 2019

ISSN 2620-8091, Online 2620-3812

\section{ABSTRACT}

To reduce the unemployment rate, Indonesia has focused since 2007 on the development of Vocational Education and Training (VET). VET is one of solutions that would enhance human resources quality in Indonesia, which has 262 million people. However, the number of unemployed graduates from vocational education is still high until 2019. It means there is something wrong in Indonesia's current VET system. Meanwhile in Germany, VET is a pillar of national education which is based on a dual system. This system is successful in Germany. As one of the biggest donor countries in promoting VET, Germany tries to introduce a dual education system through bilateral relations with developing countries such as Indonesia. Indonesia seems to need to try to develop VET base on dual education system through cooperation with Germany. Thus, the research question of this article is "why does Indonesia need to make a co-operation with Germany in developing VET based on a dual education system?' To answer the research question, this paper uses qualitative method which results in the following conclusion: Cooperation with Germany makes Indonesia gain support in developing the VET system in this country and get transfer of knowledge and technology from Germany as a developed country. Moreover, the cooperation would open the opportunity for abundant human resources in Indonesia to fulfill a huge labor demand in Germany particularly and Europe in general.

Keywords: Indonesia, Germany, Cooperation, VET, Dual Education System

\section{ABSTRAK}

Untuk mengurangi tingkat pengangguran, Indonesia fokus pada pengembangan Pelatihan dan Pendidikan Kejuruan (PPK) sejak 2007. PPK adalah salah satu solusi yang akan meningkatkan kualitas sumber daya manusia di Indonesia yang dihuni oleh 262 juta orang. Namun, jumlah lulusan yang menganggur dari pendidikan kejuruan masih terbilang tinggi hingga 2019. Ini berarti ada yang salah dalam sistem PPK Indonesia saat ini. Sementara di Jerman, PPK merupakan pilar pendidikan nasional yang didasarkan pada sistem ganda. Sistem seperti ini berhasil di Jerman. Sebagai salah satu negara donatur terbesar yang mempromosikan PPK.

Please Cite This Articel As : Astrid Wiriadidjaja et al., Indonesia-German Cooperation in Vocational Education and Training: Journal of Local Government Issues (LOGOS), https://doi.org/10.22219/LOGOS.Vol2.No2.178-192 
Jerman berusaha memperkenalkan sistem pendidikan ganda melalui hubungan bilateral dengan negara-negara berkembang seperti Indonesia. Indonesia sepertinya perlu mencoba mengembangkan PPK berbasis sistem pendidikan ganda melalui kerjasama dengan Jerman. Dengan demikian, pertanyaan penelitian dari artikel ini yaitu mengapa Indonesia perlu menjalin kerjasama dengan Jerman dalam mengembangkan PPK yang berbasis pada sistem pendidikan ganda? Untuk menjawab pertanyaan tersebut, tulisan ini menggunakan metode kualitatif yang menghasilkan kesimpulan sebagai berikut: Kerjasama dengan Jerman membuat Indonesia mendapat dukungan dalam mengembangkan sistem PPK di dalam negeri dan memperoleh transfer teknologi dan pengetahuan dari Jerman selaku negara maju. Bahkan, kerjasama ini akan membuka kesempatan SDA yang melimpah di Indonesia untuk mengisi permintaan pasar tenaga kerja yang besar di Jerman khususnya dan Eropa secara umum.

Kata Kunci: Indonesia, Jerman, Kerjasam, PPK, dan Sistem Pendidikan Ganda.

\section{INTRODUCTION}

Indonesia is not only blessed with abundant natural resources, but also abundant human resources. It is populated by 262 million people as the best assets a state can have. If these assets are developed effectively, Indonesia could become one of the world's most influential states. One of the effective ways to improve the quality of Indonesia's human capital is to develop Vocational Education and Training (VET). That is why the government has ratified the Convention on Technical and Vocational Education within Indonesia's Presidential Regulation since 2007. The purposes of improvement of the VET system in Indonesia are to transform the Indonesian VET system into one that provides demand-driven and practice-oriented programs which improve employability and participation in lifelong learning.

Moreover, Joko Widodo's administration wants the VET system to grow the labor market for skilled workers. The government plans to build more vocational schools, especially in technology, agriculture, and fisheries. The government has allocated 700 million IDR for each vocational school to enhance fun learning, with the precedence given to vocational schools in the subjects of marine and fisheries, which are the main elements of President Joko Widodo's vision for Indonesia (Pendidikan and Indonesia 2016).

The Ministry of Education and Culture (Kemendikbud) has increased its investment in VET and made its improvement a priority. In 2018, the ministry aims to make the ratio of students that enroll in general high school compared to those in vocational high schools 40:60. Since 2015, students who graduate from vocational school have been provided with an expert certification to proof their knowledge in respective fields. The making of the certification program is a part of the commitment made via AEC members, which is valid as a part of free movement of labor in all ASEAN countries.

Nowadays, the international market requires many competencies in technical skills, including the vocational area. A large demand for skilled people in the labor market comes from developed countries, especially the United States, the United Kingdom, and Germany. On the other hand, there are still a large number of people who remain unemployed in Indonesia. Based on data from the Central Statistics Agency

Please Cite This Articel As : Astrid Wiriadidjaja et al., Indonesia-German Cooperation in Vocational Education and Training: Journal of Local Government Issues (LOGOS), https://doi.org/10.22219/LOGOS.Vol2.No2.178-192 
(BPS), there are around 6.87 million people in Indonesia who are unemployed. Unemployed vocational school graduates are the largest portion of the Indonesia unemployment rate. Even though labor market demands are high, these demands are not met. It's because most Indonesian vocational graduates don't have the right set of skills.

In this case, Indonesia needs to take lessons from countries that have a qualified and strong VET system such as Germany. VET is a pillar of Germany's education system which has important function in the economy. It is a lifelong learning that is essential to a knowledge-based financial system and society. Germany sees lifelong mastering as a way of improving both the employability of its residents and a way to produce a more knowledgeable citizenry.

Germany operates a dual program in which public vocational training schools work together with privately owned companies. The system of duality - VET in the vocational college and business enterprise ensures well-qualified and expert employees. The VET machine serves the promises of the social market economy in two ways. Firstly, it increases the well-being of society via its good consequences on the competitiveness of the economy. It also it allows many to participate in enhancing the economy (Raggatt 1988).

Germany is one of the world's biggest donors in promoting VET. The German Federal Ministry for Economic Cooperation and Development developed VET strategies which can be implemented internationally. For making global improvement on VET, the ministry's main task is to make comprehensive advisory services for the gradually developing VET trends. For Germany, promoting VET aims to strengthen bilateral and multilateral relations, and also international cooperation.

Based on the background mentioned above, one can ask why Indonesia needs to make a co-operation with Germany in developing VET, based on dual education system. Basically, the purpose of this study highlights the importance of cooperation between states, mainly in education as one of the crucial aspects of society. Besides, the central topic of this study is the large amount of unemployment in Indonesia. VET policy essentially aims to make everyone who tries to achieve prosperity able to obtain good education and qualifications. Before analyzing the problem, the following section explains the literature review regarding the VET conditions in other developing countries, the theoretical framework and the methodology of research.

\section{VET in Studies}

Vocational is a common term in any education world. Thus some researches have been done to develop vocational systems in some countries, especially those with a big population such as Pakistan and Brazil. Some scholars who have researched this topic are Usman Mustafa, Kalbe Abbas, and Amara Saeed. In

Please Cite This Articel As : Astrid Wiriadidjaja et al., Indonesia-German Cooperation in Vocational Education and Training: Journal of Local Government Issues (LOGOS), https://doi.org/10.22219/LOGOS.Vol2.No2.178-192 
the article "Enhancing Vocational Training for Economic Growth in Pakistan", they discuss how VET can be used to improve the economy in a developing state with a big population like Pakistan.

In Pakistan, VET is provided by public and private sectors. Besides, there are also formal and informal apprenticeship programs. Even though there is no central organization that directly manages training centers, there are organizations that manage teacher training for VET institutions called the National Training Bureau and the National Staff Training Institute. In 2004, there were a total of 546 VET institutions with capacity of 204,670 people in Pakistan. According to the data from the Directorate of Manpower in 2005, the overall evaluation for VET programs in Pakistan was 'fair'. It means VET in Pakistan was developing even though it still needed some improvements on the skills required in the job market (Mustafa, Abbas et al. 2005).

Meanwhile, according to Asian Development Bank (ADB) data on the Labor Market Survey in 2004, the preparedness of VET graduates for skills demanded is still unsatisfactory as 58\% employees need 3-6 months on-the-job training, and 36\% employees need 6-9 months on-the-job training. Mustafa, Abbas, and Saeed concluded that the training programs needed to be more effective to reduce the duration of the job training.

Other scholars who discussed vocational education are André Portela Souza, Lycia Lima, Amanda Arabage, Juliana Camargo, Thiago de Lucena, and Sammara Soares. They analyzed VET trends increase in Brazil from 2005 to 2015. In the article titled "Vocational Education and Training in Brazil: Knowledge Sharing Forum on Development Experiences”, D'Andrea and team show the amount of enrollment in VET courses gradually increased even represented small portion of the total secondary education in Brazil (Portela Souza, Lima et al. 2015).

The increment of enrollment in VET has started since the launching of National Program for Access to Education Employment (PRONATEC) in 2011. This program was one of the main initiatives of President Dilma Roussef's government that aimed to widen the offer of professional education and improve the livelihood of people living in poverty. The program consists of initial and ongoing training for entry into the labor market. Courses in PRONATEC are free and the participants receive food, transport, and school supplies (Portela Souza, Lima et al. 2015).

There is also an S-System for private institutions that provide VET provides $43 \%$ of professional and technical education in Brazil. In this system, the institutions receive public funds through taxation of firms' payrolls. Alongside the advancements of VET in Brazil, there are still challenges to overcome. The main challenges are the mismatch between supply and demand of professional skills and lack of transparency from government and VET provider institutions (Portela Souza, Lima et al. 2015).

Please Cite This Articel As : Astrid Wiriadidjaja et al., Indonesia-German Cooperation in Vocational Education and Training: Journal of Local Government Issues (LOGOS), https://doi.org/10.22219/LOGOS.Vol2.No2.178-192 
Overall, both Pakistan and Brazil are developing states with big populations. These two states have realized the importance of VET and have focused on its development. Basically they have similar challenges when implementing VET programs. That is the difficulty of making and implementing the programs effectively in order to reduce the gaps between the supply and demand of professional skills. In Pakistan, the problem is in the absence of central organization that can provide VET programs. This matter makes the quality of VET still unsatisfactory. Meanwhile, the progress of Brazil's VET system is more promising. Even though Brazil still lacks government transparency, it has launched the PRONATEC and S-System that has become a unification system for VET in Brazil.

Unlike these studies, which only show the government's efforts in developing a VET system, this research analyzes the cooperation between two states in labor demand and supply. That is why this research uses a qualitative method through the lens of liberalism in international relations study. Principally, qualitative research is carried out to build knowledge through understanding and discovery. The qualitative research approach is a process of research and understanding which is based on methods that investigate a social phenomenon and human problems (Miles, Huberman et al. 2014).

The essence of qualitative research is observing people in the environment they interact in, related to the focus of research with the aim of trying to understand and explore their views and experiences to obtain information or the data required. The researcher's role in a qualitative method is as a key instrument in collecting and interpreting data. For data collection, this research uses document studies. Therefore, the techniques that will be used in this study are reviews of documents, such as books; journals; news; websites; and other papers that written by observers and experts.

The scope of this research is limited on the cooperation between Indonesia and Germany in building VET system in this country. Meanwhile, the term of period took range from 2014 to 2018. In analyzing the data, researcher used a liberalist perspective. One of the liberalist's assumptions which match this research is economic or other forms of interdependence or interconnectedness among states and non-state actors as tending to pacify each other or at least have a moderating effect on state behavior (Viotti and Kauppi 2019).

\subsection{Interdependence and International Cooperation in Theory}

The world is now has become interdependent in all aspects, especially in the economy. Interdependence happens when the actors in the world politics including states and non-state actors have a significant mutual relationship with each other. For Keohane and Nye, interdependence is defined as mutual dependence resulting from the types of international transactions catalogued by transnationalism. Interdependence is when there are reciprocal though not necessarily symmetrical effects among countries or among actors in different countries (Viotti and Kauppi 2019).

Please Cite This Articel As : Astrid Wiriadidjaja et al., Indonesia-German Cooperation in Vocational Education and Training: Journal of Local Government Issues (LOGOS), https://doi.org/10.22219/LOGOS.Vol2.No2.178-192 
In the interdependence era, actions and policies made by an actor can also affect others significantly. That is why relations between countries are generally in the form of cooperation, rather than conflict or competition. States cooperate with each other because they have common interest and each state has the need to fulfill their own interests. The result of cooperation is world stability and peace.

Discussion of international cooperation theory includes the relationship between two states or the relationship between larger units which is also called as multilateralism. Although the form of cooperation often starts between two states, the main focus of international cooperation is multilateral cooperation. Multilateralism is defined as a form of institution that regulates relations between three or more states based on generally accepted behavioral principles expressed in various ways. Institutional forms including international organizations, international regimes, and a phenomenon that has not yet manifested itself, namely international order (Pfaltzgraff 2001).

State actors establish cooperative relationships through international organizations and international regimes, defined as a set of agreed rules, regulations, norms, and retrieval procedures of decision making. Cooperation can be defined as a series of relationships that are not based on violence or coercion and have been legalized, such as in international organizations like the United Nations or European Union. Cooperation can be created as a result of behavioral adjustments. Cooperation can be carried out in the negotiation process or because each party is mutually exclusive so that no more negotiations are needed (Pfaltzgraff 2001).

The main challenge of the cooperation theory is based on fulfilling personal interests, where the results are benefiting both parties and can be obtained by working together. There are several reasons why a state cooperates with other states: 1) to increase economic prosperity 2) to improve efficiency related to the reduction of costs 3) to minimize problems that threaten joint security and 4) to reduce the negative losses caused by individual state actions that have impacts on other states (Holsti 1970).

\subsection{VET as a Concept}

VET is the most heterogeneous kind of education. It is difficult to define VET as a single institutional entity as it is related to other parts of education and training systems. Based on this diversity, the European Center for the Development of Vocational Training (CEDEFOP) made a general definition of VET. This definition is also used around the world as the definition that is sufficiently broad to be accepted by most stakeholders. According to CEDEFOP, VET is education and training which aims to equip people with knowledge - know-how, skills, and/or competencies required in particular occupations or more broadly in the labor market.

Please Cite This Articel As : Astrid Wiriadidjaja et al., Indonesia-German Cooperation in Vocational Education and Training: Journal of Local Government Issues (LOGOS), https://doi.org/10.22219/LOGOS.Vol2.No2.178-192 
Meanwhile, Kemendikbud defines VET as a specialized education that covers all types and levels of employment. VET is not limited to education that is solely focuses on human skills, but also focuses on the mentality, local wisdom, and attitude of the students. Therefore, it can be said that VET implicitly contains elements of cognition (thinking), activity (psychomotor), and feeling (affective) in different proportions following the skills and competency needed and level of work involved. Kemendikbud also stated that vocational education is available at all levels of education: primary, secondary, and tertiary. It also shows that every job require different human resources qualifications and competencies (Pendidikan and Indonesia 2016). People can get vocational education at high school and college which graduate with diploma status. Some study programs in Indonesian's VET are multimedia animation, accounting, engineering, shipping, tourism, pharmacy, automotive, fashion, culinary and many others.

\section{Dual Education System in German's VET Condition}

The education system in Germany is called a dual system, because it is consisted of two kinds of system. Those are on-the-job training and theoretical education in vocational training schools. The characteristic of this system is theoretical knowledge and practical skills are combined already during the training. Dual system participants are able to learn how to cope with the constantly changing demands and to appreciate the variety of social relationships that exist in the working life (Graf 2013).

During on the job training, employees are trained at the workplace while they are also doing the actual job. A professional trainer or an experienced employee serves as the course instructor using hands-on training, often supported by formal classroom training. After the training, employees will get a certificate or license. But, not all vocational schools in Germany apply the Dual Education system. There are 2 groups of vocational secondary schools in Germany.

First, Vollzeit is full time learning at school. This kind of school doesn't apply the dual system. The learning process takes place at school for 6 days a week and becomes a full responsibility for the school. If at any time students need a practicum, students can practice with one government agency or industry. However, they are not employees and they are not paid. Second, Teilzeit is half the time studying in school and half the time working in industry. This kind of school applies the dual system. So the students are working like employees and get a salary. One of the examples is Einzelhandle Vocational Schools in Bremen. They have three days working or 24 hours a week in industry and two days studying or 12 hours a week at school (Raggatt 1988).

The dual system is strongly linked with the German VET, the main characteristic of which is the cooperation between companies and vocational schools. This cooperation is regulated by the law. Students and trainees in the dual system generally spend section of every week at a vocational faculty and

Please Cite This Articel As : Astrid Wiriadidjaja et al., Indonesia-German Cooperation in Vocational Education and Training: Journal of Local Government Issues (LOGOS), https://doi.org/10.22219/LOGOS.Vol2.No2.178-192 
the different phase at a company, or they can also spend longer durations at every area before alternating. Dual system program typically lasts about two until three years. The Vocational Training Act of 1969 delivered this close relation between the Federal Government, the federal states (the 'Länder'), and companies to offer youths with training in nationally recognized occupations (Raggatt 1988).

It is estimated that there are currently around 330 occupations that require formal training in Germany. Trade unions and employer agencies support the update and modernization of VET regulations. Certificates are standardized in all industries at some stages in the states. This ensures that all apprentices receive equal opportunity without discrimination. Employers have belief in these certificates as they are the legal proof of what skills an individual is capable of. The shared accountability between government, employers, and trade unions helps in overcoming the rising new challenges, such as digital innovations that will have a growing influence on the manufacturing sector. The digital revolution will require many adjustments in the occupational world and VET policies (Deissinger 2015).

\subsection{Indonesia's VET Condition}

Vocational school in Indonesia was established for the first time in 1853, under VOC governance. It was called the Ambachtsschool van Soerabaia (Carpentry School of Surabaya). In the beginning, these vocational schools with various sorts of specialties were only for the lower to middle class, either Eurasians or Europeans (Pendidikan and Indonesia 2016). There were 88 vocational schools in Indonesia at the end of Dutch rule (1942-1945). These kinds of schools still remain in Indonesia until today, with some modifications in the names and curriculum. To show government concern about VET, Susilo Bambang Yudhoyono regulated "the Convention on Technical and Vocational Education" in Indonesian President Regulation number 102 of 2007

But the impact of the regulations was not significant. In 2018, the Central Statistics Agency (BPS) noted that the open unemployment rate (TPT) in Indonesia experienced a downward trend, amounting to $5.34 \%$. However, Saryadi, the Head of Sub Directorate of Vocational Alignment and Industrial Cooperation of Vocational Development of Kemendikbud, said there were still seven million unemployed people in Indonesia. The amount of unemployment is due to changes in the world of work and employment opportunities. The number of vocational graduates which were unemployed reached more than $8.92 \%$ of the total of unemployed people in Indonesia. The following graphic shows Indonesian unemployment rate base on level of education.

Please Cite This Articel As : Astrid Wiriadidjaja et al., Indonesia-German Cooperation in Vocational Education and Training: Journal of Local Government Issues (LOGOS), https://doi.org/10.22219/LOGOS.Vol2.No2.178-192 


\section{Unemployment Rate in Indonesia According to Education Level}

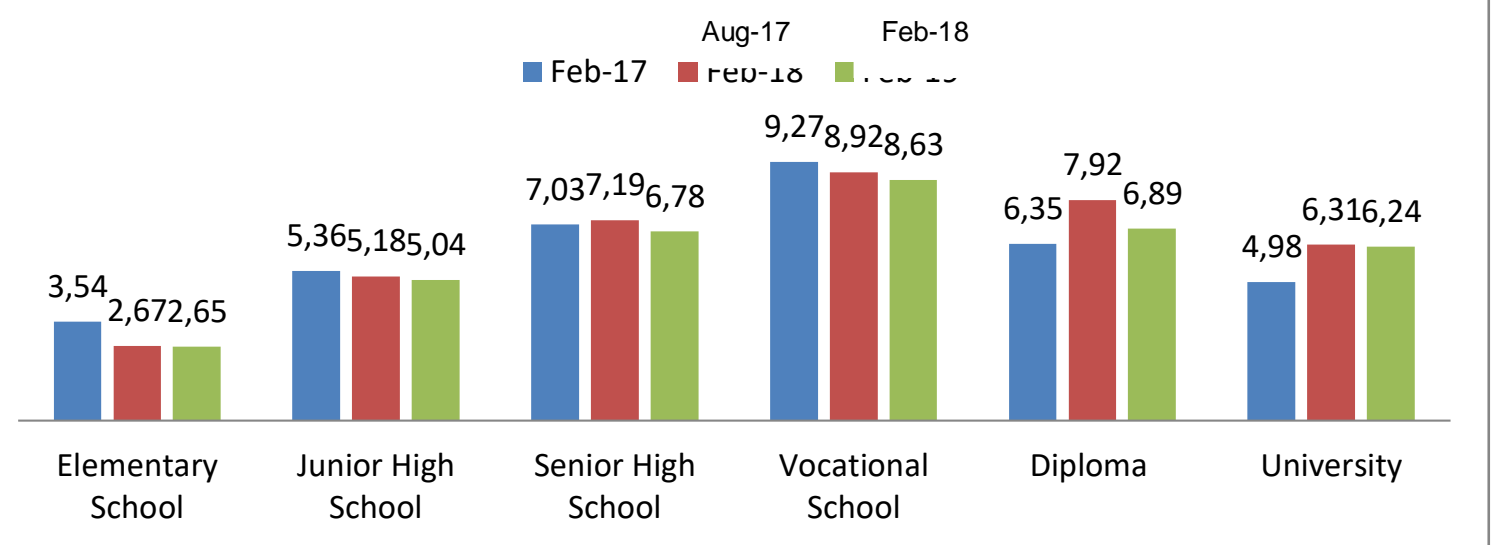

Sumber: BPS

The graphic shows vocational graduates either from school or diploma courses still dominating unemployment figures in Indonesia. Therefore, there is something wrong with the vocational education system nationally. Some problems of Indonesia's VET system lie in the lack of certified instructors, minimal facilities and infrastructure, and people's mind set.

Related to Indonesian mindset on VET, Indonesian parents usually view vocational graduates negatively because of the low salaries, unclear professional progress, and low academic competency. Chen's study (2009) affirms the parents' fears about vocational education. The study shows SMA graduates usually obtained higher earnings than SMK graduates. When it is compared to university graduates, the parents assume that studying in college is incomplete with a diploma degree. Many people say "Vocational education is not educational enough." This assumption drives the parents to send their children to get a bachelor's degree. They hope their children can get better jobs and income. This condition makes the demand for vocational school in Indonesia weak (Chen 2009).

The negative view of VET continues at school, at college, and in the workplace. Most Indonesians assume vocational graduates can only occupy technical positions when entering the labor market. In fact, such assumptions have begun to discredit them since they were students. The chairman of the students' executive council (BEM) of vocational Indonesia University complained about discrimination regarding committees frequently occurring in the implementation of campus events. Most vocational students are placed in technical divisions, such as medical, security, and logistics while the divisions that are considered prestigious, such as events and sponsors, are always filled by undergraduate students. Eventually, the Indonesian mindset that 
considers VET a non-prestigious program results in the low demand for vocational schools (Kadir and Bachrul 2016).

Another problem in the Indonesian VET system is in the national curriculum. Referring to the gap between skills which students learn at schools and competencies which workers need in the job markets, the curriculum still leaves a mismatch between abilities and skills which are needed by vocational graduates. The focus of financial development in vocational education has shifted from agriculture to manufacturing and supplier sectors. This has resulted in scarcity of suitable professional workers in the manufacturing and export-oriented sectors.

\section{Indonesia-Germany Cooperation in Developing Indonesia's VET System}

On July 2012, Susilo Bambang Yudhoyono and Angela Merkel signed the 'German-Indonesian Joint Declaration of Comprehensive Partnership: Shaping Globalization and Sharing Responsibility'. The two leaders agreed on eight areas of cooperation, namely: economic cooperation (Trade and Investment), education, research and technology, health, defense industry, food security, food energy, and transportation. In Jokowi's first administration, Indonesia-Germany relations explored a new cooperation in developing VET.

Indonesia Ministry of National Development Planning (BAPPENAS) and the German Ministry of Economic Cooperation and Development signed a "Declaration of Intent between Indonesia and Germany on the Strengthening and Deepening of the Partnership in the Field of Technical and Vocational Education and Training” on May 2017 (BAPPENAS, 2017). Both sides agreed to strengthen the Indonesian-German partnership in the field of VET. The partnership on VET is a part of bilateral technical cooperation between the governments of Indonesia and Germany, financed by the Government of the Federal Republic of Germany.

The cooperation of Indonesia and Germany focuses on three matters: 1) development of vocational education instruments in industry 2) the establishment of infrastructure to improve teacher and trainer qualifications 3) empowerment of business organizations in Indonesia to establish coordination between schools and industries (BAPPENAS, 2017). The important thing is how this mutual cooperation is able to face Indonesia's current challenges.

The first challenge facing Indonesia is the presence of the fourth industrial revolution. There is no factor driving the change in world civilization as strongly as the industrial revolution which results in technological progress. Unlike the third industrial revolution when the machine worked itself, in the fourth industrial revolution era, all machines will be connected with others, relying on a cyber-physical system that will change radically our way of life, work, and communication.

Please Cite This Articel As : Astrid Wiriadidjaja et al., Indonesia-German Cooperation in Vocational Education and Training: Journal of Local Government Issues (LOGOS), https://doi.org/10.22219/LOGOS.Vol2.No2.178-192 
Work which is done manually by relying on human power will be replaced by information and communication technology (ICT). Approximately, the composition of 35 peercent of workforce that has basic skills now will change in 2020 and almost 2 billion workers risk losing their jobs. Indonesia should prepare abundant human resources with skills and valuable services to fulfill labor market demands, either at national, regional, or global levels (Trilling and Fadel 2009).

The next challenge is regionalism and globalization. Various socio-economic changes in Indonesia up to the year 2030 must be in the regional (ASEAN) and global context. The enactment of The ASEAN Economy Community (AEC) that started at the end of 2015 will increase labor mobility and free competition among people in Southeast Asia. The AEC has various implications for the development of human resources. Most ASEAN members expect that the AEC will be a driving force for a skill-intensive economy. It is because they have moved towards production and export which require high technology skills to support productivity (Pendidikan and Indonesia 2016).

BPS estimated the demand for skilled workers in Southeast Asia will increase around $41 \%$ or 14 million people from 2010 until 2025. Half of that number will be in Indonesia, followed by the Philippines with needs of skilled workers of 4.4 million. According to the AEC scenario, in 2025 there will be an increase of 1.9 million job opportunities in Indonesia, around 1.3\% of total employment (Office 2014). This will not only be in Southeast Asia, as developed states, there is a lot of demand for skilled workers in high-tech developed countries such as Germany, the United States, and the United Kingdom.

Related to mutual cooperation with Indonesia, Germany itself has a lot of demand for highly skilled workers inside the country. The urgency for highly skilled workers in Germany derive from demographics that causes labor shortage. The demographic change in Germany is relatively fast compared to other European countries or the US, for example. In Germany, the relative size of the labor market entry cohorts (the share of those aged 15 to 24 relative to those aged 15 to 64) has been decreasing significantly since the $1980 \mathrm{~s}$. It is roughly 10 percentage points lower (Garloff and Wapler 2016).

According to the Cologne Institute for Economic Research on behalf of the Association of German Engineers (Verein deutscher Ingenieure/VDI), there were an average of 72,000 vacancies for engineers which could not be filled in 2011 (Garloff \& Wapler, 2016). This condition shows that Germany is one of the EU countries with the highest skill demand in the labor market. It can be a good opportunity for Indonesia to fulfill this labor market demand. Moreover, cooperation with Germany in a dual VET system would make vocational graduates in Indonesia adjust to German skilled worker standards.

But, there is a note that needs attention as the last challenge to developing a VET system in Indonesia. The dual education system is difficult to export outside Germany and not all states can successfully create this 
kind system within their country. Based on the projects made by Germany in exporting their dual VET system, the collaborative training structures were largely unsustainable. One of the examples is the project with the Philippines. Between the year 1996 and 2007, there were ten projects that Germany and Philippines made with one common aim: the nationwide introduction and establishment of dual VET programs. Looking to the evaluation based on relevance, effectiveness, efficiency, impact, and sustainability, the export of Germany's dual education system to the Philippines was unsatisfactory because the sustainability was inadequate (Euler 2013).

It has been not only developing states that have tried to implement Germany's VET system. Developed states like South Korea also made Germany their role model. Germany introduced a Dual VET system in 2005 at the Conference of Human Resources Development Service of Korea. By reforming their VET system, South Korea's government tried to implement Germany's dual education system to increase the labor market orientation. The reformed system that included shared-financing was introduced to increase the number of in-company training positions. Government enforced higher tax for companies with more than 300 employees that provided fewer training positions than the number specified by the government (Ji-Yeon 2014).

That shared financing system was expected to increase training positions for the employees. When the government tried to reduce the tax, the number of training positions available in companies fell again. It means that the method used by South Korea to implement Germany's VET system was ineffective because it only makes the companies afraid of high tax but it did not change their mindset on the importance of VET. In other words, the absence of changes in mindset among companies and industries in South Korea made the export of Germany's dual education system to South Korea unsuccessful (Ji-Yeon 2014).

\section{CONCLUSION}

Vocational education in Indonesia only continues the tradition that existed before. Since 2007, the government has started to focus on developing a VET system in the country. It specifically legitimized "the Convention on Technical and Vocational Education" in Indonesian President Regulation number 102 of 2007. After taking the regulation step, Indonesia's government under Joko Widodo tried to actualize the real efforts to fix a VET system within the country. One of these efforts was organizing 700 million IDR for each vocational school especially for marine and fisheries subjects. But, these efforts seem to have failed to produce highly skilled vocational graduates. Vocational graduates are the highest unemployment group compared to the unemployment rate of university graduates or any other school graduates. In this case, Indonesia needs to seek role model to develop a VET system in the country.

On the other hand, Germany is a developed country which promotes a VET system globally. Through the platform of dual education system, Germany introduces and teaches this kind system to developing 
countries, includes Indonesia. This kind of system does not only create technologically highly skilled workers, but also integrates the companies as stakeholders of the involvement of industry in the education system. This image would be a great opportunity for Indonesia to strengthen the partnership with Germany. For Germany itself, cooperation with Indonesia is not only about how to get the market and to make investments, but also to shape and to reach skilled workers.

In liberalism lens, interdependency and cooperation between state actors is very common nowadays. More exactly, there is no single state that could fulfill all its needs without cooperating with other states. At least there are three reasons why Indonesia needs to cooperate with Germany in developing VET which is based on a dual education system.

First, cooperation with Germany makes Indonesia gain support in improving and developing the VET system in this country. The Dual VET system would be a solution in producing high-skilled vocational graduates which match labor demand. Second, as a developing country, Indonesia can get transfer of knowledge and technology from Germany as a developed country. If this is achieved, teachers, trainers, students, and vocational graduates would be ready to face the future of the fourth industrial revolution. Third, cooperation with Germany would open the opportunity for abundant human resources in Indonesia to fulfill a huge labor demand in Germany particularly and Europe in general. Applying dual VET system in the Indonesian curriculum would make vocational students and graduates automatically adjust to European standard because some countries such as Austria, Switzerland, Luxembourg, and Denmark have already used the dual education system.

Finally, the increasing in vocational graduates bargaining position would change the Indonesian perspective on VET. Moreover, VET would be a favorite program in Indonesia. Just remember that not all states can implement a dual education system within their different backgrounds. Dual system has been growing in Germany over a period of time and under special conditions, it can't be adapted fully by other states within a short period.

There are some factors that would challenge in applying dual VET system in Indonesia. Geographically, Indonesia is the world's largest archipelago. Even nowadays, distribution in education is still not equal and equity. Demographically, Indonesia is the world's fourth most populous country. In the midst of abundant human resources, there is a shortage of teachers and lecturers for vocational education. Moreover, using a dual VET system in Indonesia has to adjust with the socio-cultural conditions in this country, especially people's mindsets. Government willingness to improve VET is the only hope to reform the vocational system at national level.

Please Cite This Articel As : Astrid Wiriadidjaja et al., Indonesia-German Cooperation in Vocational Education and Training: Journal of Local Government Issues (LOGOS), https://doi.org/10.22219/LOGOS.Vol2.No2.178-192 
Considering that Indonesia-Germany cooperation in vocational education just began in 2018, this article is only baby step in studying a dual VET system in Indonesia. In the future there should be a potential research to supervise and analyze Indonesia-Germany cooperation in implementing a dual VET system in the country.

\section{REFERENCES}

Chen, D. (2009). Vocational Schooling, Labor Market Outcomes, And College Entry: Vocational Schooling, Labor Market Outcomes, And College Entry, The World Bank.

Deissinger, T. (2015). "The German dual vocational education and training system as 'good practice'?" Local Economy 30(5): 557-567.

Euler, D. (2013). "Germany's dual vocational training system: a model for other countries?".

Garloff, A. and R. Wapler (2016). "Labour Shortages and Replacement Demand in Germany. The (Non-) Consequences of Demographic Change."

Graf, L. (2013). The hybridization of vocational training and higher education in Austria, Germany, and

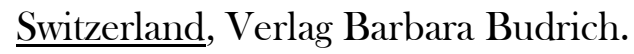

Holsti, K. J. (1970). "National role conceptions in the study of foreign policy." International Studies Quarterly 14(3): 233-309.

Ji-Yeon, L. (2014). "Vocational Education and Training in Korea: Achieving the Enhancement of National Competitiveness." Korea Research Institute for Vocational Education and Training, Report, Korea.

Kadir, S. and B. Bachrul (2016). "Technical and Vocational Education and Training in Indonesia: Challenges and Opportunities for the Future." Lee Kuan Yew School of Public Policy, Microsoft Case Study on Series on Technical and Vocational Education and Training, Singapore.

Miles, M. B., et al. (2014). Qualitative data analysis: A methods sourcebook. 3rd, Thousand Oaks, CA: Sage.

Mustafa, U., et al. (2005). "Enhancing vocational training for economic growth in Pakistan."

Office, I. L. (2014). ASEAN Community 2015: Managing Integration for Better Jobs and Shared Propserity, International Labour Office.

Pendidikan, K. and K. R. Indonesia (2016). Revitalisasi Pendidikan Vokasi, Jakarta.

Pfaltzgraff, R. L. (2001). Contending theories of international relations: a comprehensive survey, Longman.

Please Cite This Articel As : Astrid Wiriadidjaja et al., Indonesia-German Cooperation in Vocational Education and Training: Journal of Local Government Issues (LOGOS), https://doi.org/10.22219/LOGOS.Vol2.No2.178-192 
Portela Souza, A., et al. (2015). Vocational Education and Training in Brazil: Knowledge Sharing Forum on Development Experiences: Comparative Experiences of Korea and Latin America and the Caribbean, Inter-American Development Bank.

Raggatt, P. (1988). "Quality control in the dual system of West Germany." Oxford Review of Education 14(2): 163-186.

Trilling, B. and C. Fadel (2009). 21 st Century Skills.: Learning for Life in Our Times, John Wiley \& Sons.

Viotti, P. R. and M. V. Kauppi (2019). International relations theory, Rowman \& Littlefield Publishers.

Please Cite This Articel As : Astrid Wiriadidjaja et al., Indonesia-German Cooperation in Vocational Education and Training: Journal of Local Government Issues (LOGOS), https://doi.org/10.22219/LOGOS.Vol2.No2.178-192 